\title{
Archipel
}

ARCHIPEL Études interdisciplinaires sur le monde insulindien

$100 \mid 2020$

Varia

\section{Singing to Buddha: The Case of a Buddhist Rock Band in Contemporary Indonesia}

Chanter pour Bouddha: le cas d'un groupe de rock bouddhique dans l'Indonésie contemporaine

Jack Meng-Tat Chia

\section{CpenEdition}

\section{Journals}

Electronic version

URL: http://journals.openedition.org/archipel/2131

DOI: 10.4000/archipel.2131

ISSN: 2104-3655

\section{Publisher}

Association Archipel

\section{Printed version}

Date of publication: 15 December 2020

Number of pages: 175-197

ISBN: 978-2-910513-84-9

ISSN: 0044-8613

\section{Electronic reference}

Jack Meng-Tat Chia, « Singing to Buddha: The Case of a Buddhist Rock Band in Contemporary Indonesia », Archipel [Online], 100 | 2020, Online since 28 November 2020, connection on 04 December 2020. URL : http://journals.openedition.org/archipel/2131 ; DOI : https://doi.org/10.4000/archipel. 2131 


\section{Singing to Buddha: The Case of a Buddhist Rock Band in Contemporary Indonesia ${ }^{2}$}

\section{Introduction}

In the spring of 2016, when I was conducting research in Jakarta, I met with a Singaporean friend (and informant) who was there on vacation for a few days. That evening over dinner, he enthusiastically shared with me about an upcoming Buddhist Vesak Day concert in Singapore, called "Sadhu for the Music," that he was helping to organize. "Sadhu for the Music," as he told me, would be the first collaborative music concert featuring Buddhist organizations from Indonesia, Malaysia, and Singapore. ${ }^{3}$ My friend, knowing that I am working on the history of Buddhism in Indonesia, asked me if I have heard of an Indonesian Buddhist band known as "True Direction." "They perform Buddhist rock music that resembles those Christian praise

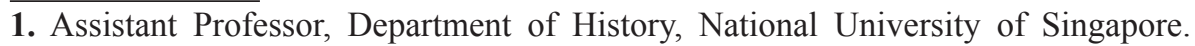
Email: jackchia@nus.edu.sg.

2. Earlier versions of this article were presented at the 2018 Association for Asian Studies Annual Conference, the Multiplicity of Asian Buddhist Modernities Conference, and the Oldenborg Luncheon Colloquium at Pomona College. I am grateful to James Benn, Penny Edwards, Ming-yen Lee, Scott Mitchell, Zhiru Ng, Robert Sharf, Erick White, and two anonymous reviewers for their helpful comments. I would also like to thank Tan Guan Fan, Ardy Wong, and Irvyn Wongso for their time and assistance. This work was supported by an Overseas Postdoctoral Fellowship and a Start-Up Grant from the National University of Singapore.

3. For more information on the "Sadhu for the Music" Concert, see Sadhu for the Music (2016). 
and worship songs, you know?" he said excitedly. He went on to share with me about True Direction's latest song, "Dhamma Is My Way," and their "cool" music videos on YouTube. This made me really curious about the Buddhist band. When I returned home that night, I immediately looked up True Direction's YouTube channel and Facebook page, and was intrigued by their seemingly "Christianized" songs and religious activities. Given my research on Indonesian Buddhism and my interest in Buddhist music, I began to consider the possibility of investigating the history and activities of True Direction. Subsequently, with the assistance of a few friends, I was in touch with the organization's founder, Irvyn Wongso, and learnt more about the Buddhist group from various online and printed sources.

Buddhism is one of the six officially recognized religions in presentday Indonesia. A broad range of Buddhist traditions are present in the country, including Theravāda, Mahāyāna, Vajrayāna, as well as the localized Buddhayāna movement. According to the 2010 Indonesian national census, Buddhists make up approximately $0.7 \%$ (around 1.7 million) of the total population in the world's largest Muslim country (Sensus Penduduk 2010). Previous studies on Buddhism in modern Indonesia have attempted to examine the Buddhist "revival" by offering a broad historical overview of the development of Buddhism in the twentieth century (Barker 1976; Ishii 1980; Kimura 2003; Linder 2017; Steenbrink 2013; Suryadinata 2005). A number of scholars have focused their attention on Ashin Jinarakkhita, whom Indonesians consider to be the first Indonesian-born Buddhist monk, and his controversial monotheistic concept of "Sang Hyang Ādi-Buddha" during Indonesia's New Order period (1966-1998) (Bechert 1981; Brown 1987; Chia 2017; Chia 2018; Ekowati 2012). Some recent studies have observed the resurgence of Chinese culture, language, and religion in the post-New Order era, highlighting the growth of Buddhism in many parts of Indonesia (Suprajitno 2011; Suprajitno 2013; Syukur 2010). Despite this so-called Buddhist "revival" and the burgeoning scholarship on Indonesian Buddhism, there is no study thus far that examines the production and performance of Buddhist music in contemporary Indonesia. ${ }^{4}$ This article, therefore, aims to shed some light on Indonesia's Buddhist music through the case of a Buddhist music organization in Jakarta.

Buddhologists and ethnomusicologists have paid much attention to the role of music in Buddhist traditions. ${ }^{5}$ Francesca Tarocco (2001) in her review essay points out that Buddhist music associated with diverse traditions and practices can be seen in South, Southeast and East Asia, as well as in Western Buddhist

4. Several previous studies examine the relationship between Buddhism and music in Indonesia during the Hindu-Buddhist period. See, for instance, Becker (1971); Harnish (1993/94).

5. For a bibliography of Buddhism and Music, see Szczepanski (2014). 
communities. She suggests that scholarly research on Buddhist music can be broadly divided into three categories, namely, 1) liturgical practices involving choral chanting and instruments; 2) para-liturgical and ritual practices; and 3) contemporary new Buddhist music. Comparatively, scholars of Chinese and American Buddhist music traditions have also classified Buddhist music into three categories. While Pi-yen Chen (2005) suggests that the "three mainstream genres" of Chinese Buddhist music are Buddhist chant, devotional song, and commercial music, Scott Mitchell (2013) notes that the three forms of Buddhist music that are prevalent in America are Buddhist chants, devotional and liturgical music, and popular musical expressions. A review of previous literature reveals that liturgical and ritual music are the types of Buddhist music that have received the most scholarly attention (see Chen 2001; Qing 1994; Szczepanski 2014). Responding to these gaps, a handful of scholars have started to pay closer attention to varied forms of "new" Buddhist music, such as "rock music," "hymn," and "popular music" in contemporary society (Cupchik 2016; Lin 2012; Mitchell 2014; Steen 1998). To this end, this study attempts to explore why and how Indonesian Buddhists compose and perform what scholars would consider "contemporary new Buddhist music" or "popular music" (Mitchell 2013; Tarocco 2001) in present-day Indonesia.

This article uses the case of True Direction to explore the development and performance of Buddhist music in contemporary Indonesia. I argue that although True Direction's music in many ways resembles contemporary Christian music, the organization does not produce contemporary Buddhist songs - or "Buddhist rock" as I call this form of religious music - to replace Buddhist devotional practices with Christian-style worship service. By Buddhist rock, I refer to rock music with lyrics focusing on the tenets of Buddhist faith and teachings. While Irvyn Wongso and his colleagues, like their Christian counterparts, rely on religious rock music as an evangelical tool to attract a younger audience, they consider contemporary Buddhist music as complementary, rather than alternative, to existing Buddhist devotional practices. ${ }^{6}$ Instead of mimicking Christian worship, True Direction functions as a music school for training Buddhist musicians and promotes rock songs alongside common Buddhist devotional practices. Thus, this study reveals that Indonesian Buddhists are "local geniuses" in the selective adaptation of popular music to repackage Buddhist doctrine and attract young followers in contemporary Indonesian society. ${ }^{7}$

6. Christian churches have used contemporary rock music known as praise and worship music in their religious services. For studies on Christian rock songs, see for instance, Bacchiocchi (2000); Goh (2008); Howard and Streck (1999); Reid Jr (1993).

7. H. G. Quaritch Wales coins the term "local genius" to describe local Southeast Asians that fused local elements and Indian influences in the development of Southeast Asian cultures during the Hindu-Buddhist period of the region's history. See, for instance, Wales (1951); Wolters (1999). 
The present study is based on fieldwork, interviews, and online research conducted between 2015 and 2018. It draws on a wide range of materials, including interviews with True Direction's founder, Irvyn Wongso, and the group's former vocalist, Ardy Wong; newspaper and magazine articles; online videos and photo albums; and social media postings. This article is divided into four sections. The first section offers a brief background to the history of Buddhism in modern Indonesia. The second presents a biography of Irvyn Wongso, and discusses the establishment and evolution of True Direction. The third examines the production and performance of contemporary Buddhist songs by True Direction. The final section investigates True Direction's activities, revealing that the organization produces Buddhist rock songs to complement, not replace, Buddhist devotional practices in present-day Indonesia.

\section{A Brief History of Buddhism in Modern Indonesia}

Buddhism in present-day Indonesia has little, if not nothing, to do with the Hindu-Buddhist kingdoms of Srivijaya and Majapahit. Most Buddhists in Indonesia today are ethnic Chinese who migrated to the Dutch East Indies during the colonial period or descended from immigrant ancestors. In 1619, the Dutch East India Company (Verenigde Oost-Indische Compagnie) founded Batavia (present-day Jakarta) and encouraged Chinese merchants, who had long been engaging in the spices trade at the neighboring port kingdom of Banten, to migrate to Batavia. The Chinese served the Dutch as contractors and tax farmers, recruited laborers and craftsmen from China, and supplied bricks and timber for buildings and city walls in the Dutch colonial port settlement over the next two centuries (Kuhn 2008). The arrival and settlement of Chinese immigrants contributed to the spread of Chinese Buddhism into the Dutch East Indies from as early as the seventeenth century. Kim Tek Ie (Jinde yuan 金德院, also known as Vihāra Dharma Bhakti), the oldest Buddhist temple in Indonesia, was established in 1650 in Glodok, a Chinese district in the southwest of Batavia. It was a popular place of worship among the overseas Chinese community and served as a residence for Chinese migrant monks. However, little is known about the identity of these monks and their religious activities in Batavia (Franke et al. 1997: xliv-5; Salmon and Lombard 1980: xviii) From the temple inscriptions, it appears that the kapitan and his Chinese community leaders were behind the management and funding of the temple, while monks were mainly ritual specialists serving the overseas Chinese community (Franke et al. 1997: 11-13).

Subsequent large-scale Chinese migration to the East Indies began in the mid-nineteenth century and lasted through the 1930s (Kuhn 2008). Indonesian Buddhists have generally considered Venerable Pen Ching (Benqing 本清, 1878-1962, also known as Mahasthavira Aryamula) as the first Chinese monk to actively propagate the Dhamma in the Dutch East Indies (Lembaga Litbang 
Majelis Buddhayana Indonesia 2005). Pen Ching was born in 1878 in Fujian, China. At the age of 19, he became a novice at Guanghua Monastery (Guanghua si 廣化寺) under the tutelage of Venerable Thung Chan (Tongzhan 通湛). In 1901, Pen Ching traveled south to Dutch Java for the first time to propagate the Dhamma. He resided at the Tay Kak Sie (Dajue si 大覺寺), an eighteenth century Chinese temple located in Semarang, Central Java, where he taught the Dhamma for three years before returning to China. After his return, Pen Ching was nominated as abbot of the Guanghua Monastery, but he declined the invitation, and went back to the East Indies in the following year. In 1926, Pen Ching went to Jakarta and resided in a hut in the yard of a small Buddhist shrine, known as the Jade Lotus Hall (Yulian tang 玉蓮堂), in Petak Sinkian. When the shrine was relocated in 1949, the ownership of the land was transferred to Pen Ching. By then, the Chinese Civil War (1946-1949) with the impending Communist victory meant that Pen Ching could not return to China. Thus, he decided to settle in Indonesia and expanded the shrine into a monastery. In 1951, Pen Ching established the Kong Hoa Sie (Guanghua si 廣化寺), named after the Guanghua Monastery in China, which became an important Chinese Buddhist temple in postcolonial Indonesia (Chia 2018; Juangari 1995; Majelis Buddhayāna Indonesia 1990; Salmon and Lombard 1980).

Pen Ching's disciple, Ashin Jinarakkhita (1923-2002), also known as Ti Chen Lao He Sang (Tizheng Laoheshang 體正老和尚), is widely regarded as the first Indonesian-born Buddhist monk (biksu pertama putra Indonesia). ${ }^{8}$ Born in 1923 to a Chinese immigrant family in Bogor, a city in West Java, Ashin Jinarakkhita developed interest in Buddhism from his visits to Chinese temples (klenteng) at a young age. During his studies in the Netherlands, Ashin Jinarakkhita became an active member of the Theosophical Society, where he began to study the teachings of major world religions and became particularly interested in Buddhism. His growing interest in Buddhism led him to the decision of fully devoting himself to the study and propagation of the faith. In 1953, Ashin Jinarakkhita organized the first national Vesak celebration at the ancient Buddhist site of Borobudur, restoring the monument into a place of worship. Later that year, he was ordained as a novice under Pen Ching at Kong Hoa Sie. A year later, he received his higher ordination and studied insight meditation (vipassanā) in Burma under the tutelage of Mahāsi Sayādaw (1904-1982). In 1955, Ashin Jinarakkhita returned to Indonesia and started his Buddhayāna movement, which had a profound impact in Indonesia during the second half of the twentieth century. He crafted an inclusive and non-sectarian vision of Indonesian Buddhism, which combined the doctrines and practices of Theravāda, Mahāyāna, and Vajrayāna, as a diverse, yet unified religion in line with the motto of "Unity in Diversity" (Bhinneka Tunggal Ika) of the postcolonial Indonesian nation (Chia 2018; Juangari 1995).

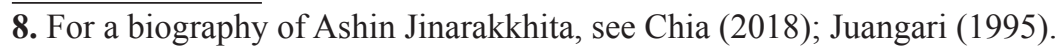


During the New Order era (1966-1998), the Suharto regime was suspicious of Chinese Indonesians' ties to communist China and introduced a repressive ethnic policy to assimilate the Chinese Indonesian population. The Indonesian government promulgated a series of laws and presidential orders to assimilation (pribumization) aimed at Chinese Indonesians (Suryadinata 2007: 266). Furthermore, following a ban on all Chinese events in public, Buddhist temples were not allowed to organize religious ceremonies for Chinese festivals, such as the Lunar New Year, the Hungry Ghost Festival, and the Mid-Autumn Festival. Consequently, Buddhists could no longer use Chinese languages and characters in their liturgy and scriptures (Chia 2018: 52-53). As told to me by my informants, Mahāyāna scriptures and mantras in Chinese had to be transliterated into Roman alphabet during the New Order period. Therefore, the Buddhayāna organizations turned to Pālilanguage texts together with a selection of transliterated Chinese Buddhist texts for their liturgical and ritual practices (Ananda 2015; Dharmavimala Thera 2015). In addition, Ashin Jinarakkhita introduced the controversial concept of "Sang Hyang Ādi-Buddha" to make Buddhism compatible with the first principle of the Pancasila, the five philosophical pillars of Indonesia (see Brown 1987; Chia 2018; Ekowati 2012; Kimura 2003). Although Ashin Jinarakkhita's concept of Sang Hyang Ādi-Buddha was accepted by Suharto's government, thus ensuring the survival of Buddhism during the New Order era, he faced opposition from his Theravādin disciples and colleagues who claimed that he was deviating from "pure" Buddhist teachings. Consequently, five of his disciples left the Buddhayāna Sangha and founded a new Theravāda organization in Indonesia (Chia 2018: 58-59).

Despite numerous restrictions on Chinese religious institutions and practices during the New Order period, there was a burgeoning of Buddhist organizations in Indonesia during the 1970s. For this reason, the Suharto government recognized a need to unify the various Buddhist organizations under a national umbrella association. In May 1978, a Buddhist congress was held in Yogyakarta to form the Representatives of Indonesian Buddhists (Perwalian Umat Buddha Indonesia, hereafter WALUBI). At its establishment, WALUBI became the umbrella federation of three Sangha organizations, namely, Sangha Theravāda Indonesia, Sangha Mahāyāna Indonesia, and Sangha Agung Indonesia (SAGIN), and seven lay Buddhist organizations, namely, Majelis Agama Buddha Nichiren Shōshū Indonesia, Majelis Buddha Mahāyāna Indonesia, Majelis Dharma Duta Kasogatan, Majelis Pandita Buddha Dhamma Indonesia, Majelis Pandita Buddha Maitreya Indonesia, Majelis Rohaniawan Tridharma Seluruh Indonesia, and Majelis Buddhayāna Indonesia (MBI) (Chia 2018; Lembaga Litbang Majelis Buddhayana Indonesia 2005; Syukur 2010). ${ }^{9}$

9. In 1995, WALUBI expelled Ashin Jinarakkhita's SAGIN and MBI from the national Buddhist association. See Chia (2018); Suryadinata (1997). 
Following the fall of Suharto and the anti-Chinese riots in May 1998, Indonesia went through a process of democratization and reformation (reformasi). The post-Suharto era saw the lifting of Chinese assimilation legislations and an increase in democratic space. This gave rise to the revival of Chinese culture, language, media, and religious practices (Hoon 2008; Setijadi 2016; Stenberg 2019). Concomitantly, there was a resurgence of Chinese festival celebrations and religious rites at Buddhist temples in various parts of Indonesia (Suprajitno 2011; Suprajitno 2013; Syukur 2010). In the course of my fieldwork in Indonesia over the last few years, I have noticed that the younger generation of Chinese Indonesians born during the New Order identify themselves as Buddhists. Although many of them can neither read nor speak Chinese, they are now learning to recite Chinese-language Buddhist scriptures using texts in pinyin romanization. But more interestingly, I have observed that a number of Indonesian Buddhist organizations have begun to rely on popular music to reach out to this younger generation of Chinese Indonesian Buddhists. While some temples have rearranged Buddhist chants with new instrumentation, other groups have produced and performed Buddhist popular and rock music. The establishment of True Direction and the development of its contemporary Buddhist music can therefore be understood in the context of growth and evolution of Buddhist institutions in post-New Order Indonesia.

\section{Irvyn Wongso and the Founding of True Direction}

To understand the founding of True Direction, one needs to first know its founder, Irvyn Wongso (Huang Junzhong 黄俊中, b. in 1978). True direction, as I would argue, both as a band and as an organization, is so closely intertwined with Irvyn Wongso, such that it is not possible to speak of it in either sense without referencing Wongso's ideals, values, and activities. Irvyn Wongso was born in 1978 to a middle-class Chinese Indonesian family in Medan, the capital of North Sumatra province. He indicated that both his parents are Buddhists, and his devout Buddhist mother often prayed and dedicated merits to him at temples during her pregnancy. Wongso claimed that he became interested in Buddhism at a young age, and wanted to become a monk when he was seven years old. However, Wongso's parents did not want their son to leave the household, and instead, sent him to study in a Christian missionary school, hoping that he would change his mind. At the Christian school, Wongso took bible classes and sang in a church choir. As Wongso shared with me, his churchgoing experience was the first time he realized that popular music could be used for religious activities (Wongso 2017a).

Despite his education at a Christian school, Irvyn Wongso did not convert to Christianity. On the contrary, Wongso's interest in Buddhism developed without his parents' knowledge as he learned more about Buddhist teachings from the Internet. During that time, Wongso studied the Dhamma from various 
Buddhist websites and Internet chat groups. As his knowledge of Buddhism grew, Wongso enjoyed engaging in virtual debates with other Buddhists. As Wongso candidly shared with me, he thought that he was becoming a "bad" and "quarrelsome" person by intentionally using Buddhist teachings to argue with and criticize others. Wongso subsequently turned to learning the meditation practices of Theravāda, Mahāyāna, and Vajrayāna Buddhist traditions, hoping to make himself a better person. He also traveled to various places to further his knowledge of the Buddhist teachings, claiming that he studied with lamas in Bhutan and in the Himalayas as well as forest monks in Thailand. According to Wongso, he is open to and respects the different Buddhist sects, but he identifies himself as a Theravāda Buddhist. He also said that his meditation training, coupled with his encounters with various Buddhist teachers and friends during his religious travels, inspired many of the songs he wrote and composed for True Direction, which I will discuss later (Wongso 2017a).

Just like his Buddhist belief, Irvyn Wongso became interested in music at a young age. He started learning to play the piano from his mother who was a music teacher. And to my surprise, although Wongso can play the piano quite well, he cannot read music notes and has learned everything, as he puts it, "by ear and by heart" (Wongso 2017a). After completing his middle school education, he left for high school in Western Australia, and continued his college education majoring in computer systems engineering at Curtin University in Perth, where he met his wife and they now have three sons. Wongso jokingly pointed out to me that his college degree has absolutely nothing to do with his interests in Buddhism and music, and especially, his current career in the music industry. In a strange twist of fate, Wongso returned to Indonesia after college and joined Nuansa Musik, the largest Yamaha music instrument dealer and music school in Indonesia, and had risen through the ranks to become the Chief Executive Officer and President Director of the company with some 850 employees under his charge (Wongso 2016a; Wongso 2017a).

Given his interest in Buddhism and music, Irvyn Wongso considered the possibility of using music to propagate the Buddhist teachings. In an online autobiographical interview, he highlights the intertwining relationship between Buddhism and music, explaining how music can be used as a tool to propagate the Dhamma and unite Buddhist communities around the world:

For as long as I can remember, music and Buddhism is [sic] almost like water and oil. But we need both in our life. Don't you think? For many years, I've been a Buddhist. I've learned the Dhamma from all three different traditions. My bed sides are full of Dhamma books. I even hiked the Himalayan Mountains. Stayed in cave somewhere in the Thai forest to practice meditation. I never thought that I need music for my spiritual progress. Until one day, I noticed that many of my friends are turning their backs away from the Dhamma. And my children, they are listening to music which are not even suitable for them far from the Dhamma. And my Mum, she told me when she die [sic], she doesn't need all those rituals, just play her my song. So maybe I don't need music, but we all need the Dhamma. 
Don't you think? And music can open the door to Dhamma, just a little bit wider. Music also unites, not only people but also nations. Now we have come together as one, joining hands, to walk together in the path of the Dhamma, and to share the Dhamma through music (Wongso 2016b).

As the reference to his views on Buddhism and music suggests, Irvyn Wongso believes that music can bring his family and friends to study the Buddha's teachings. More importantly, he considers music as an ecumenical platform to unite Buddhists not only to learn the Dhamma, but also to share it with others. In my interview with Wongso, I probed more into his interest in Buddhist music and his motivations behind the establishment of True Direction. He candidly revealed his observation of the Buddhist scene in present-day Indonesia and highlighted the need for a Buddhist youth organization:

In Indonesia, people only go to vihara or temple on special days. Many people come just to pray and get blessings from the monks. But on normal days, they don't come. And those who come are usually the [elderly] aunties and uncles who have nothing to do at home. And another group of temple-goers are the young kids - the Sunday school children. They are there because their parents just need some sort of cheap childcare when they go out on Sundays. So that is why they put their kids there. But I notice that there is a missing link between the young kids and the older generation. And it's the youths! There are obviously many reasons why they don't go to temples willingly. One thing is because we haven't been able to communicate the Dhamma through their language properly... You know, Dhamma is very deep and beautiful but if you don't speak to youths in their language, it means nothing to them. We need to attract more youths to come and learn the Dhamma. In my [music] industry, the curriculum for music classes is changing every year and we learn to teach music better... but we don't have this in Buddhism. So [Buddhists] assume that everyone loves to meditate and read the Abhidhamma. ${ }^{10}$ One thing I feel that is crucial in our society not just today, but forever, is music... But we don't have many of this in Buddhism. So True Direction aims to [spread the] Dhamma through music (Wongso 2017a).

On June 16, 2015, Irvyn Wongso founded True Direction to achieve his aspiration of spreading Buddhism with the use of popular music that appeals to the young. According to him, the organization had its origins in the auditorium of his music company in Jakarta, which looks just like a Christian church auditorium (see Figure 1). Irvyn Wongso points out that the vision of True Direction is to become an "International Buddhist Musicians Fellowship" that "practices the Buddha Dhamma, gives positive contribution to the community and active in sharing the Dhamma especially through music" (True Direction 2018; Wongso 2017a). True Direction has five objectives: 1) to improve the

10. The Abhidhamma Pițaka is one of the three pițakas (Pāli for "baskets") constituting the Pāli Canon, the standard collection of scriptures in the Theravāda Buddhist tradition. The Abhidhamma contains scholastic and philosophical analysis of the Buddha's teachings in the Sutta Pițaka (Pāli for "Basket of Discourse"). See, for instance, Bodhi (2000). 


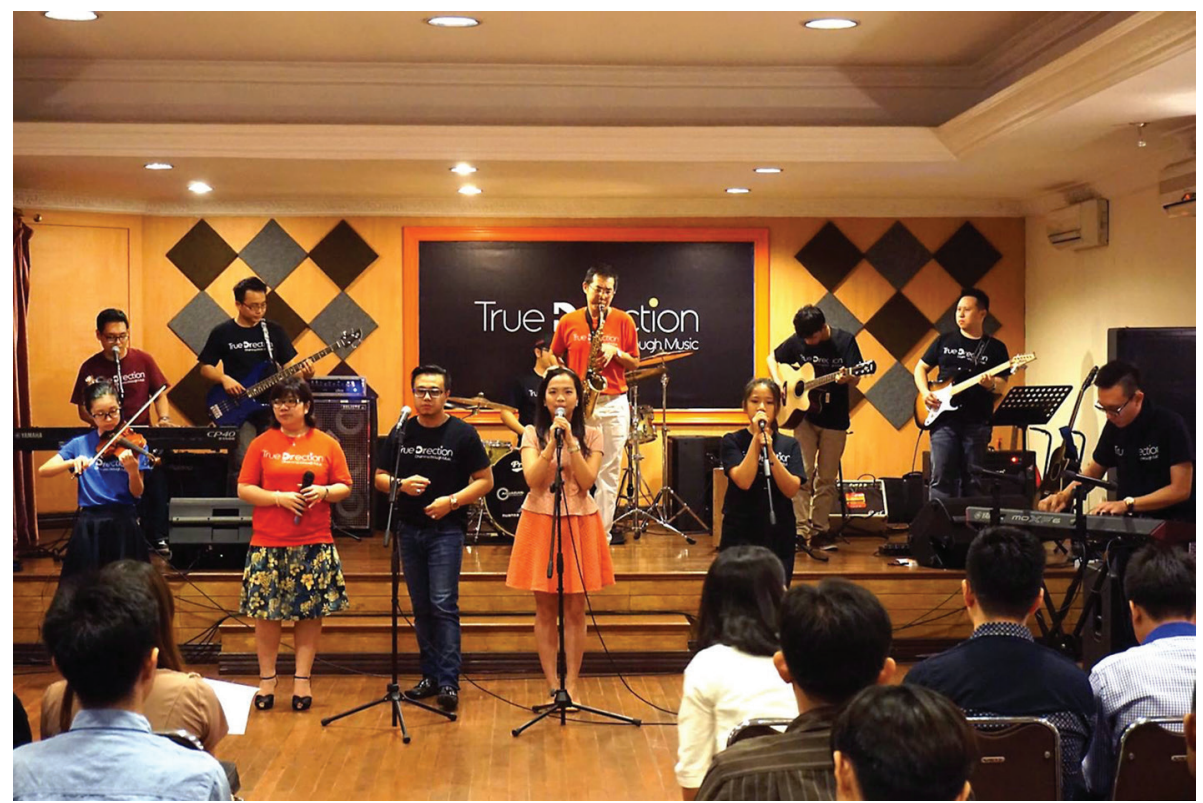

Fig. 1 - True Direction's "Menuju Puncak” (Towards the Peak) Monthly Gathering. Photo courtesy of True Direction.

quality and competency of Buddhist musicians through workshops and training to meet the needs of the changing world; 2) to create high quality and distinctive Dhamma music that would be accepted by the community to inspire positive transformation; 3) to create a space for Buddhist musicians to grow, receive support in music composition, and to feel appreciated for their effort; 4) to serve as a venue for Buddhist musicians to deepen their understanding and practice of the Dhamma in their daily lives; and 5) to share the Dhamma and happiness with the society, and direct them to the noble path (True Direction 2018). The organization has been quite successful in recruiting young members since its establishment. According to Wongso, True Direction has approximately 120 musicians and most of its members are Chinese Indonesians between the ages of 15 and 40. The organization has grown quickly, and it currently has several hundred members and over 4,000 likes on Facebook (True Direction 2018; Wongso 2017a). My engagement with the followers indicates that most of them are Chinese Indonesians from middle-class backgrounds. Many of them are either college students or graduates in various professional fields.

It is significant to note that True Direction operates quite differently from the majority of the Buddhist organizations in Indonesia. First, Irvyn Wongso mentions that he has yet to formally register True Direction as a religious organization with the Indonesian government and does not intend to make 
his organization a typical Buddhist temple. Rather, he wants True Direction to function as a music school that produces contemporary Buddhist songs and trains Buddhist musicians in western instruments, such as guitar, piano, drum, and keyboard. Therefore, the organization focuses on running music workshops, composing Buddhist songs, and spreading Buddhist music on various social media platforms. Second, Wongso encourages open membership in his organization. Although Wongso identifies himself as a Theravādin, he wants True Direction to remain non-denominational and welcomes Buddhists from all traditions to join his organization. Furthermore, True Direction also conducts music workshops for Buddhists from other temples, hoping that they will form their own bands and use contemporary Buddhist songs for Dhamma propagation in their respective organizations in the long run (Wongso 2017a). For instance, Ardy Wong, whom I will discuss later, was one of the key vocalists for True Direction's band before leaving to set up another Buddhist rock band in Indonesia (Wong 2017).

True Direction serves as an intriguing case study to understand the development of contemporary Buddhist music, demonstrating how rock songs are used as a tool for evangelizing the younger generation. To quote Wongso's (2017a) own words, the attempt to "share the Dhamma through music" with youths involves the production of contemporary Buddhist songs as well as the training of Buddhist musicians in western instruments and popular music. The transformation of Buddhist music, from liturgical chant to religious rock, formed the basis for the production of True Direction's first music album, which I will examine in the following section.

\section{The Making of Buddhist Rock}

A few months after its establishment, True Direction released its first music album Dhamma is My Way (see Figure 2), which contains nine contemporary Buddhist songs in English and Indonesian languages: 1) "Mari Melangkah" (Let's Go); 2) "Yang Patut Dimuliakan" (The Honored One); 3) "Akhir Dari Semua Dukkha" (End of All Suffering); 4) "Dhamma Is My Way"; 5) "Sang Tiratana" (The Triple Gems); 6) "Tiada Badai" (No Storms); 7) "Malam Suci Waisak" (The Holy Night of Vesak); 8) "Beautiful Heart, Peaceful Mind"; and 9) "Semoga Semua Hidup Berbahagia" (May All Beings Be Happy). ${ }^{11}$ These songs have combined rock and popular music with lyrics presenting the tenets of Buddhist faith and doctrine. The song album is available for purchase in Indonesia and for paid online downloads (iTunes 2015).

11. The album also contains the instrumental versions of the songs "Dhamma Is My Way" and "Semoga Semua Hidup Berbahagia." See Musixmatch (2015). 


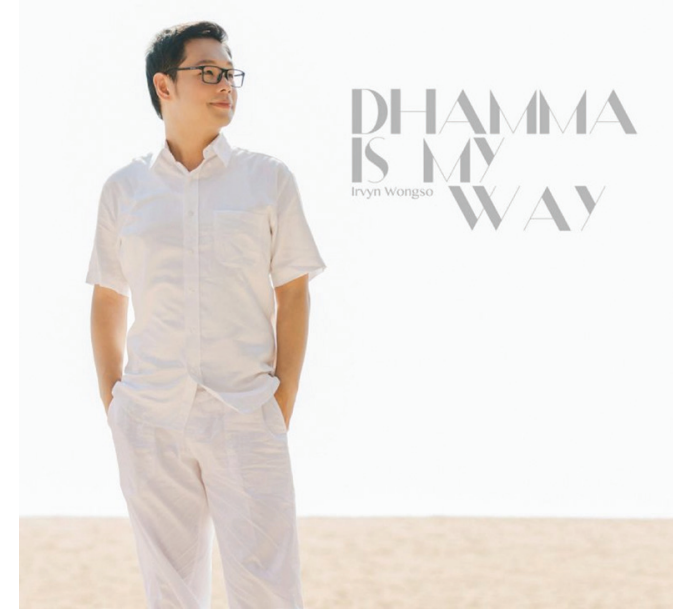

Fig. 2 - Dhamma Is My Way Music Album. Photo courtesy of True Direction.

The lead song "Dhamma Is My Way," which is the only English song in the album, closely resembles a Christian praise and worship song (True Direction 2016). However, it is clear that Irvyn Wongso, who wrote the music and lyrics, was quick to point out to me that contrary to what many people had thought, he did not receive the inspiration to write the song from Christian rock music, but from practicing meditation in a cave in northern Thailand. He claimed that his meditation experiences helped him understand the "truth" that the Buddha taught and made him realize that "the Dhamma is [his] way to happiness and salvation" (Wongso 2017a). Regardless of whether Wongso's meditation experiences are meant to be taken literally or have been stylized to fit the expectations of his Buddhist colleagues and members, it is clear that Wongso recognizes that music serves as an effective tool for him to share his faith with the younger generation.

\section{"Dhamma Is My Way"12}

I've been looking for so long,

Through the darkest path of all.

Climbing up only to fall, again,

To find the one eternal light.

In the darkest time of night, I see the beautiful moonlight.

Through the darkest time of life,

I finally see the truth.

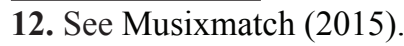


The truth that blows away,

The dark clouds in my mind,

Now I have found the way.

\section{Chorus:}

Only Dhamma is my way,

From now and forever.

No other way is mine,

Until the end of time.

Another popular song from the album, "Semoga Semua Hidup Berbahagia" (May All Beings Be Happy), is based on the Pāli phrase, "Sabbe sattā sukhi hontu." The lyrics, which are based on teachings from the Mettā Sutta (Discourse on Loving-Kindness), are translated in the table below. According to Irvyn Wongso, he wrote this Indonesian-language song as a prayer for all sentient beings, hoping that they will always be well and happy.

\section{"Semoga Semua Hidup Berbahagia"13 \\ (May All Beings Be Happy [translation mine])}

Semua yang disini,

Wahai saudaraku,

Mari satukan hati,

Pancarkan cinta kasih.

Bebaskan diri dari dengki,

Yang mencengkram hati,

Kembali disini,

Hanya di saat ini.

Dengan penuh ketulusan,

Dan kelembutan,

Kepada semua,

Di segenap alam.

Reff:

Semoga semua hidup berbahagia,

Aman dan selamat,

Sehat sejahtera.

Selamanya...
Everything here,

$\mathrm{O}$, my brother,

Let's unite our hearts,

[And] Radiate loving kindness.

Free yourself from envy,

That grips the heart,

Come back here,

Only in this moment.

With full sincerity,

And tenderness,

To all,

In all of nature.

Chorus:

May all beings be happy,

Safe and trouble-free,

Healthy [and] well.

Forever...

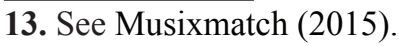


In her study of Chinese Buddhist music, Pei-yen Chen (2005) considers Buddhist devotional song (fojiao gequ 佛教歌曲) as songs "rather than commercial in intent, have been meant to promote Buddhism" (Chen 2005: 272 ) and Buddhist commercial music (shangpin fojiao yinyue 商品佛教音 樂) as "fashionable" Buddhist music that "does not necessarily emphasize evangelism," "follows the form of western art songs," and "produced by record companies" (Chen 2005: 277). However, in the case of the Dhamma Is My Way album, we see an interesting fusion of Buddhist devotional song and commercial music. True Direction produces contemporary Buddhist songs in the form of rock music for devotion and evangelism, and at the same time, aims to sell their music albums in the commercial music markets in Indonesia and on the Internet.

Following the release of Dhamma Is My Way music album, True Direction organized several "Dhamma sharing" tours to promote the album in various parts of Indonesia, including Jakarta, Medan, Tangerang, and Yogyakarta. The organization also produced several music videos for the songs in the album and made them freely available on the Internet (True Direction 2016; Wongso 2017a). A number of recent studies have pointed out that Buddhist organizations began to rely more heavily on the Internet and various social media platforms for Dhamma propagation and to connect with their young members (see Cheong et al. 2011; Huang 2017). True Direction is also quick to jump on this bandwagon and has utilized YouTube and social media platforms, such as Facebook, Instagram, and Twitter to promote the music videos of their songs. As Irvyn Wongso explains, many young people in Indonesia are not interested in visiting temples or reading the Buddhist scriptures. Since many of them spend their leisure time surfing the web and swiping their smartphones, Wongso believes that posting Buddhist songs and messages on social media sites that young people regularly visit is an effective strategy to reach out to them (Wongso 2017a). The songs in album became a hit among young Buddhists in Indonesia and among Buddhist youth groups in the region. From my online research, I observed that some of the Buddhist youths in Indonesia, who are unaffiliated with True Direction, performed these songs and had them recorded and uploaded online (see, for instance, Citta Obhasa 2018; Harijanto 2017; The ALPADH 2016). Therefore, building on the vision of "Dhamma through music," Irvyn Wongso reveals that his long-term plan for True Direction is to propagate the "Dhamma through films," such as short films and feature animations (Wongso 2017a).

Since most of the songs in the album are in Bahasa Indonesia, True Direction's primary audiences are Indonesian teenagers and young adults between the ages of 15 and 40 years old. However, Irvyn Wongso was surprised that the songs were also well-received by Buddhists in Malaysia and Singapore. For example, when the Singaporean Buddhist community organized the "Sadhu for the Music," a joint music concert featuring Buddhist musicians from Indonesia, Malaysia, and Singapore in 2016, True Direction was among one of the organizations invited 
to perform at the event (Sadhu for the Music 2016). Notably, the Singaporean organizers gave Irvyn Wongso the honor of performing a duet with renowned Malaysian Buddhist composer and singer, Imee Ooi (Huang Huiyin 黄慧音), who is known for performing new arrangements and compositions of Buddhist chants in a "calming and relaxing" manner (Loo et al. 2012: 7072). For the final piece of the concert, a duet entitled "The Metta Moment," Irvyn Wongso sang Imee Ooi's "Chant of Metta," while Ooi performed Wongso's "Semoga Semua Hidup Berbahagia" (Wongso 2016c).

Subsequently, True Direction was invited to perform at various Buddhist organizations in Malaysia and Singapore, such as the Bodhi Buddhist Fellowship Malaysia (Puti Gongzuofang 菩提工作坊) in Kuala Lumpur, the Buddhist Gem Fellowship in Malacca, and the Buddhist Fellowship in Singapore (Anonymous Video 2017; BGF Youth Connection 2016; Wongso 2016d). Bodhi Buddhist Fellowship's youth band recorded a rearranged version of "Semoga Semua Hidup Berbahagia," which added a new rap in English (Bodhi Buddhist Fellowship Malaysia 2016).

Several conclusions can be drawn from True Direction's Buddhist rock and their religious activities. First, True Direction's contemporary Buddhist songs and its modern auditorium, at least on the surface, resemble more of a Christian church than a Buddhist temple. In fact, the album cover of Dhamma Is My Way looks uncannily similar to Hillsong Church's former worship pastor, Darlene Zschech's album cover, Change Your World (see Zschech 2015).${ }^{14}$ This probably explains why some Indonesian Buddhists are critical of and disagree with True Direction's music and activities, which I will discuss in the next section. Second, True Direction has relied on various forms of new media to market Buddhist rock to a younger audience. The organization utilizes the Internet and social media platforms to reach out to the younger generation of Indonesians with little or no interest in Buddhism, hoping that "fashionable" contemporary Buddhist music will entice them to find out more about the Buddhist teachings, and eventually convert to Buddhism. More importantly, True Direction has worked closely with regional Buddhist organizations to exchange information and knowledge on Buddhist music. The increase in religious networking among so-called "reformist" Buddhist organizations at various levels-local, regional, national, and international - allows likeminded groups to exchange ideas, share resources, collaborate on activities, and build "a sense of communitas" in the region (Kuah-Pearce 2003: 291).

14. Hillsong Church is a charismatic Christian megachurch in the western suburbs of Sydney, Australia. The church is known for its production and performance of Christian worship songs with their music groups such as Hillsong United, Hillsong Worship, and Hillsong Young \& Free. See Connell (2005); Goh (2008). 


\section{From Buddhist Rock to Meditation Retreat}

Despite its success in the local and regional Buddhist scene, True Direction and its contemporary music are not spared criticism from a number of Indonesian Buddhists. In an interview with Buddhist magazine, Buddhazine, Irvyn Wongso laments that some Indonesian Buddhists are "conservative" and frown upon the use of contemporary Buddhist music in Dhamma propagation. He also reveals that the "unappreciative" attitude of the Buddhist community affected the sales of True Direction's music albums. Wongso emphasizes that, on the contrary, Indonesian Christians and Muslims who knew about him and his music, gave him a "thumbs up" for his innovative methods to teach and share his faith with others (Tanuwidjaja 2015).

From my fieldwork and research, I found that it is true that a number of Indonesian Buddhists are critical of Wongso and his organization. While some believed that Wongso is trying to replace existing Buddhist devotional practices with Christian-style praise and worship, others expressed concern that True Direction is promoting "unorthodox" Buddhist teachings to corrupt the minds of the younger generation. However, it is hard to gauge the proportion of Indonesian Buddhists disagreeing with True Direction's music. Interestingly, Wongso (2017a) candidly remarked that because of these "fake news" about him, as he put it, he had been "blacklisted and banned" from speaking at several Buddhist temples in Indonesia. What Wongso shared with me, nonetheless, reveals the competition between Indonesian Buddhists who adhere to familiar Buddhist devotional practices, considering themselves as "orthodox" Buddhism, and those who drastically innovate and repackage the faith to appeal to a younger audience. This tension, I argue, stems from, first, a competition for young membership among Buddhist organizations in Indonesia, and second, differences in the interpretation of what constitutes "correct" Buddhist devotional practices.

More significantly, contrary to the critics' assumption, I observed that True Direction produces contemporary Buddhist songs to complement, not replace, common Buddhist devotional practices. Although the music and image of True Direction closely resemble a modern Christian church, Irvyn Wongso emphasizes that his organization will not become a Buddhist church and introduce Christian-style worship into its activities (Wongso 2017a). In his interview with Buddhazine, Wongso discloses that he actually prefers meditation over singing and producing music albums (Tanuwidjaja 2015). Therefore, it came as no surprise when Wongso (2017a) repeatedly reminded me during our interview that it was meditation rather than Christian rock music that inspired his Buddhist songwriting endeavor.

Wongso recognizes that True Direction is successful in using Buddhist rock music as a tool to attract young people to Buddhism, but stresses that it should not be the only focus of his organization. According to him, True Direction 
organizes regular gatherings for its members to recite the Buddhist scriptures and practice meditation. This is because Wongso wants to introduce Buddhist devotional practices to young Buddhists to "deepen their understanding of the Buddha's teachings and apply the Dhamma to their daily lives" (Wongso 2017a). For this reason, common devotional practices such as scripture reading and meditation retreat are among the list of activities promoted at True Direction. For instance, Wongso organized a three-day Dhamma and Meditation Retreat for True Direction's members in December 2017 (see Figure 3). The participants followed the eight precepts, practiced sitting and walking meditation, and observed mindfulness eating during the retreat (see True Direction 2017a; True Direction 2017b; True Direction 2017c; True Direction 2017d). Some of the participants shared their meditation experiences, which were recorded and posted online (see Wongso 2017b; Wongso 2017c; Wongso 2017d).

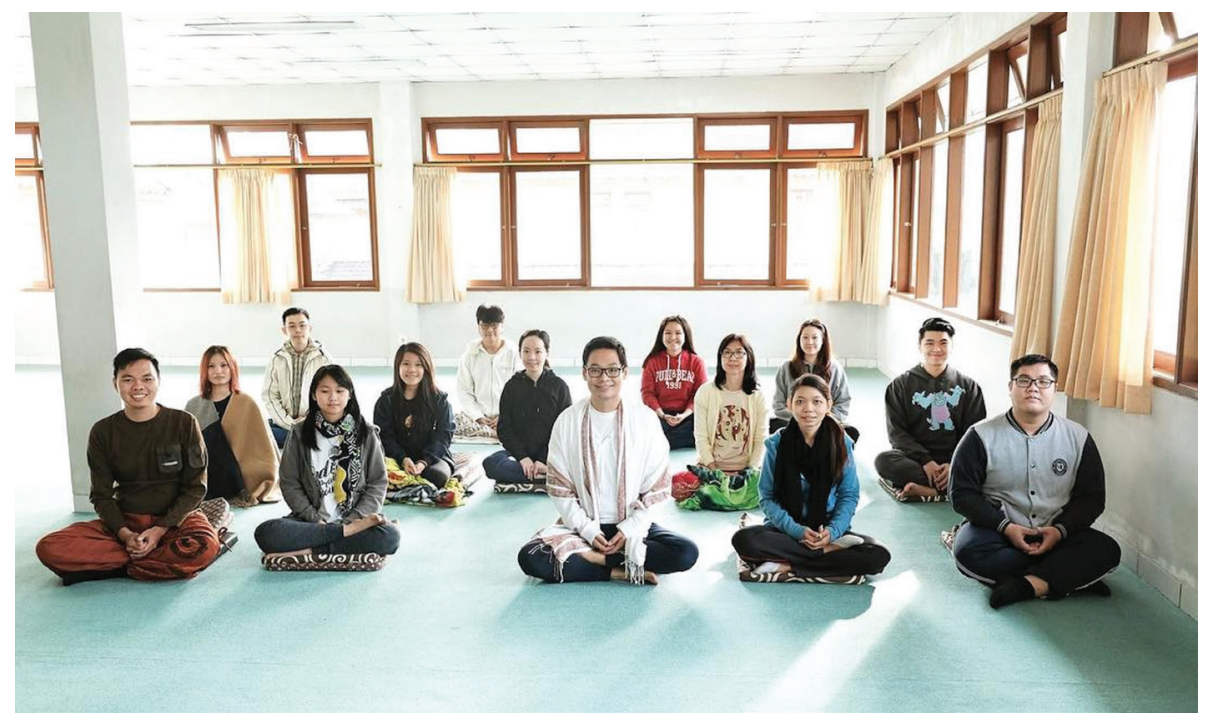

Fig. 3 - True Direction Members at a Three-day Dhamma and Meditation Retreat, December 24, 2017. Photo courtesy of True Direction.

However, some members of True Direction have recognized the potential of contemporary Buddhist songs in evangelizing youths and young adults, and considered using rock and pop music to launch Buddhist praise and worship services. For example, Ardy Wong, who was one of the vocalists for the song "Dhamma Is My Way," left True Direction to set up a Buddhist worship band called Sadhu United in April 2016 (Wong 2017). It is no coincidence that the name of the band uncannily resembles that of Hillsong United, which is a Christian worship band that started as a part of the well-known Hillsong charismatic Christian megachurch in Australia (see Connell 2005; Goh 2008). 
Sadhu United, as told to me by Ardy Wong, plans to compose and perform Buddhist rock songs, and eventually, develop into a Buddhist youth church. The band held its first Buddhist worship concert in March 2018, which attracted several hundred youths from Jakarta and its neighboring cities (SADHU 2018; Sadhu United 2018; Wong 2017). More research would be needed to shed more light on the development and performance of contemporary Buddhist music in present-day Indonesia.

\section{Conclusion}

Music has long been developed for use in liturgical and ritual practices across Buddhist traditions in Asia and beyond. In recent times, Buddhists have composed and performed new forms of Buddhist music, such as hymn, pop music, and rock and roll, to interest and attract a younger audience. This article has examined the development and performance of a form of contemporary Buddhist music, which I coin "Buddhist rock," by focusing on the case of True Direction in Indonesia. I have presented the ideals and visions of the organization's founder, Irvyn Wongso, and discussed his motivations behind the establishment of an organization that seeks to propagate the "Dhamma through music." As the study of True Direction has shown, Indonesian Buddhists are "local geniuses" in the selective adaptation of popular music to propagate the Dhamma in contemporary Indonesian society. True Direction sets Buddhist lyrics to rock and popular music to attract and evangelize a younger audience without interest in Buddhism, hoping that these new forms of religious songs will interest them to learn more about the Buddha's teachings and convert to Buddhism.

The production and performance of Buddhist rock music appears to be a double-edged sword for Irvyn Wongso and his True Direction movement. On the one hand, True Direction's innovative activities and music have successfully contributed to the growth of the organization domestically, and allowed it to receive recognition regionally. On the other hand, some Indonesian Buddhists have criticized True Direction's attempt to use "unorthodox" music to propagate the Dhamma, and are concerned that Wongso's Christian-style worship would corrupt young Buddhist minds. I have contended that although True Direction in some ways resembles a Christian church, a closer look at the organization's activities reveals that contemporary Buddhist songs have not displaced devotional observances that are commonly practiced by Buddhists in contemporary Indonesia. Contrary to the critics' claims, Wongso uses contemporary Buddhist songs as a means to complement, not replace, meditation practice and scripture reading.

This study has added a perspective that complements the rich literature on Buddhist music. Specifically, it has considered how new forms of Buddhist music have been adopted as a platform for expressing devotion and 
spreading the faith in the world's largest Muslim nation. Given the increasing popularization of contemporary Buddhist music in present-day Indonesia, it is hoped that future research will delve into the details of this religious phenomenon, including the variations across Buddhist organizations and bands, and the reasons for differences between the experiences of different founders, musicians, and followers.

\section{References}

Ananda, Michael. 2015. Interview by Author, February 9.

Anonymous Video. 2017. "Dhamma Is My Way" \& "I am Home" by Irvyn Wongso \& True Direction at BGF on 21st May 2017. https://www.youtube.com/watch?v=Vj2tvn7_Rq0 (accessed June 1, 2020).

Bacchiocchi, Samuele, ed. 2000. The Christian and Rock Music: A Study on Biblical Principles of Music. Michigan: Biblical Perspectives.

Barker, J. W. M. 1976. "Contemporary Buddhism in Indonesia." In Buddhism in the Modern World, edited by Heinrich Dumoulin and John C. Maraldo, 147-153. New York: Collier Macmillan.

Bechert, Heinz. 1981. "The Buddhayāna of Indonesia: A Syncretistic Form of Theravada." Journal of the Pali Text Society 9: 10-21.

Becker, Judith. 1971. "Hindu-Buddhist Time in Javanese Gamelan Music." In Papers from the Fourth Conference of the International Society for the Study of Time, edited by J. T. Fraser, Nathanial Lawrence, and David Park, 161-72. New York: Springer.

BGF Youth Connection. 2016. "Terima Kasih, Irvyn.” https://www.facebook.com/BgfYC/ photos/a.788493401252470.1073741870.3071540127197477/788526031249207/?type=3 (accessed June 1, 2020).

Bodhi, Bhikkhu, ed. 2000. Comprehensive Manual of Abhidhamma: The Abhidhammattha Sangaha. Onalaska: Pariyatti Publishing.

Bodhi Buddhist Fellowship Malaysia. 2016. "Semoga Semua Hidup Berbahagia-Irvyn Wongso (Cover by Plan B)." https://www.youtube.com/watch?v=6aTiloMhlpU (accessed June 1, 2020).

Brown, Iem. 1987. "Contemporary Indonesian Buddhism and Monotheism." Journal of Southeast Asian Studies 18 (1): 108-117.

Chen, Pi-yen. 2001. "Sound and Emptiness: Music, Philosophy, and the Monastic Practice of Buddhist Doctrine." History of Religions 41 (1): 24-48.

Chen, Pi-yen. 2005. "Buddhist Chant, Devotional Song, and Commercial Popular Music: From Ritual to Rock Mantra.” Ethnomusicology 49 (2): 266-286.

Cheong, Pauline Hope, Shirlena Huang, and Jessie P. H. Poon. 2011. "Cultivating Online and Offline Pathways to Enlightenment: Religious Authority and Strategic Arbitration in Wired Buddhist Organization." Information, Communication \& Society 14 (8): 1160-1180.

Chia, Jack Meng-Tat. 2017. "Museum and Hagiography: The Ashin Jinarakkhita Memorial Hall in Jakarta." Material Religion 13 (2): 272-274.

Chia, Jack Meng-Tat. 2018. "Neither Mahāyāna Nor Theravāda: Ashin Jinarakkhita and the Indonesian Buddhayāna Movement." History of Religions 58 (1): 24-63.

Citta Obhasa. 2018. "Dhamma Is My Way (cover)." https://www.youtube.com/ watch? $\mathrm{v}=11$ NiUJesCGY (accessed June 1, 2020). 
Connell, John. 2005. "Hillsong: A Megachurch in the Sydney Suburbs." Australian Geographer 36 (3): 315-332.

Cupchik, Jeffrey W. 2016. "Buddhism and Popular Music." In The Bloomsbury Companion to Religion and Popular Music, edited by Christopher Partridge \& Marcus Moberg, 144 159. London: Bloomsbury.

Dharmavimala Thera. 2015. Interview by Author, January 24.

Ekowati, Wilis Rengganiasih Endah. 2012. "Bhikkhu Ashin Jinarakkhita's Interpreting and Translating Buddhism in Indonesian Cultural and Political Contexts." In Teaching Dhamma in New Lands, 36-45. Wang Noi, Ayutthaya: The International Association of Buddhist Universities.

Franke, Wolfgang, Claudine Salmon, and Anthony K. K. Siu, eds. 1997. Chinese Epigraphic Materials in Indonesia, Volume 2 Part 1. Singapore: South Seas Society.

Goh, Robbie B. H. 2008. "Hillsong and 'Megachurch' Practice: Semiotics, Spatial Logic and the Embodiment of Contemporary Evangelical Protestantism." Material Religion 4 (3): 284-304

Harijanto, Janet. 2017. "Dhamma Is My Way by Irvyn Wongso | Janet Harijanto.” https://www. youtube.com/watch? $\mathrm{v}=\mathrm{wE}$ XtKFpJSY (accessed June 1, 2020).

Harnish, David. 1993/94. "The Future Meets the Past in the Present: Music and Buddhism in Lombok." Asian Music 25 (1/2): 29-50.

Hoon, Chang-Yau. 2008. Chinese Identity in Post Suharto Indonesia: Culture, Politics and Media. Eastbourne: Sussex Academic Press.

Howard, Jay R. and John M. Streck. 1999. Apostles of Rock: The Splintered World of Contemporary Christian Music. Lexington: University Press of Kentucky.

Huang, Weishan. 2017. "WeChat Together about the Buddha: The Construction of Sacred Space and Religious Community in Shanghai through Social Media." In Religion and Media in China: Insights and Case Studies from the Mainland, Taiwan and Hong Kong, edited by Stefania Travagnin, 110-128. New York: Routledge.

Ishii, Yoneo. 1980. "Notes on the Historical Development of Modern Indonesian Buddhism." Tonan Ajia Kenkyu 東南アジア研究 18 (2): 257-270.

iTunes. 2015. Dhamma Is My Way. https://itunes.apple.com/na/album/dhamma-is-myway/1063922284 (accessed June 1, 2020).

Juangari, Edij. 1995. Menabur Benih Dharma di Nusantara: Riwayat Singkat Bhikkhu Ashin Jinarakkhita. Bandung: Yayasan Penerbit Karaniya.

Kimura, Bunki. 2003. "Present Situation of Indonesian Buddhism: In Memory of Bhikkhu Ashin Jinarakkhita Mahasthavira." Nagoya Studies in Indian Culture and Buddhism 23: 53-72.

Kuah-Pearce, Khun Eng. 2003. State, Society and Religious Engineering: Towards a Reformist Buddhism in Singapore. Singapore: Eastern Universities Press.

Kuhn, Philip A. 2008. Chinese Among Others: Emigration in Modern Times. Singapore: NUS Press.

Lembaga Litbang Majelis Buddhayana Indonesia. 2005. Perkembangan Agama Buddha di Indonesia. Jakarta: Penerbit Dian Dharma.

Lin, Tse-Hsiung Larry. 2012. The Development and Conceptual Transformation of Chinese Buddhist Songs in the Twentieth Century. Ph.D. diss., University of California, San Diego.

Linder, Julia. 2017. Entwicklungen des Buddhismus im zwanzigsten Jahrhundert in Indonesien: Strömungen, Verwerfungen und Aushandlungen der "Agama Buddha (di) Indonesia". Frankfurt am Main: PL Academic Research. 
Loo, Fung Ying, Loo Fung Chiat, and Tee Xiao Hao. 2012. "The Calming Effect of Imee Ooi’s Buddhist Music: From Mantra to Music and Meditation." Journal of Basic and Applied Scientific Research 2 (7): 7072-7076.

Majelis Buddhayāna Indonesia. 1990. Untukmu Mahasthavira: Panitia Peringatan Hari Ulang Tahun Ke-68 dan 38 Tahun Pengabdian Y.A. Mahasthavira Ashin Jinarakkhita. Jakarta.

Mitchell, Scott A. 2013. "Buddhism and American Music." Grove Music Online (accessed June 1, 2020).

Mitchell, Scott A. 2014. "The Ritual Use of Music in US Jōdo Shinshū Buddhist Communities." Contemporary Buddhism 15 (2): 356-372.

Musixmatch. 2015. Dhamma Is My Way. https://www.musixmatch.com/album/Irvyn-Wongso/ Dhamma-Is-My-Way (accessed June 1, 2020).

Qing, Tian. 1994. "Recent Trends in Buddhist Music Research in China." British Journal of Ethnomusicology 3 (1): 63-72.

Reid Jr, John Edgar. 1993. "The Use of Christian Rock Music by Youth Group Members." Popular Music and Society 17 (2): 33-45.

SADHU. 2018. Sadhu Live In [Buddhist Worship Concert] - Official Highlight Video. https:// www.youtube.com/watch? $\mathrm{v}=2 \mathrm{r} 47 \mathrm{RrSjFao}$ (accessed June 1, 2020).

Sadhu for the Music. 2016. Sadhu for the Music. https://www.facebook.com/SadhuForTheMusic/ (accessed June 1, 2020).

Sadhu United. 2018. Home. https://www.facebook.com/SADHUunited// (accessed June 1, 2020).

Salmon, Claudine and Denys Lombard. 1980. Les Chinois de Jakarta : Temples et vie collective. The Chinese of Jakarta: temples and communal life, Paris: Editions de la Maison des sciences de l'homme (First ed. 1977).

Sensus Penduduk. 2010. "Penduduk Menurut Wilayah dan Agama yang Dianut." http://sp2010. bps.go.id/index.php/site/tabel?tid=321\&wid=0 (accessed June 1, 2020).

Setijadi, Charlotte. 2016. “'A Beautiful Bridge:' Chinese Indonesian Associations, Social Capital and Strategic Identification in a New Era of China-Indonesia Relations." Journal of Contemporary China 25 (102): 822-835.

Steen, Andreas. 1998. "Buddhism \& Rock Music: A New Music Style." CHIME: Journal of the European Foundation for Chinese Music Research 12/13: 151-164.

Steenbrink, Karel. 2013. "Buddhism in Muslim Indonesia." Studia Islamika 20 (1): 1-34.

Stenberg, Josh. 2019. Minority Stages: Sino-Indonesian Performance and Public Display. Honolulu: University of Hawai'i Press.

Suprajitno, Setefanus. 2011. Negotiating the Cultural and the Religious: The Recasting of the Chinese Indonesian Buddhist." Biblioasia 7 (3): 24-30.

Suprajitno, Setefanus. 2013. Chineseness is in the Eye of the Beholder: The Transformation of Chinese Indonesian After Reformasi. Ph.D. diss., Cornell University.

Suryadinata, Leo. 1997. The Culture of the Chinese Minority in Indonesia. Singapore: Times Books International.

Suryadinata, Leo. 2005. "Buddhism and Confucianism in Contemporary Indonesia: Recent Developments." In Chinese Indonesians: Remembering, Distorting, Forgetting, edited by Tim Lindsey and Helen Pausacker, 77-94. Singapore: Institute of Southeast Asian Studies.

Suryadinata, Leo. 2007. Understanding the Ethnic Chinese in Southeast Asia. Singapore: Institute of Southeast Asian Studies. 
Syukur, Abdul. 2010. "Keterlibatan Etnis Tionghoa dan Agama Buddha: Sebelum dan Sesudah Reformasi 1998." In Setelah Air Mata Kering: Masyarakat Tionghoa Pasca-Peristiwa Mei 1998, edited by I. Wibowo and Thung Ju Lan, 105-137. Jakarta: Kompas.

Szczepanski, Beth. 2014. "Buddhism and Music. Oxford Bibliographies," http://www. oxfordbibliographies.com/view/document/obo-9780195393521/obo-97801953935210136.xml (accessed June 1, 2020).

Tanuwidjaja, Hendrick. 2015. "True Direction: Menyebarkan Dhamma Melalui Musik." Buddhazine, http://buddhazine.com/true-direction-menyebarkan-dhamma-melalui-musik/ (accessed June 1, 2020).

Tarocco, Francesca. 2001. "Buddhist Music." Grove Music Online (accessed December 8, 2018).

The ALPADH. 2016. "Medley Dhamma Is My Way, Semoga Semua Hidup Berbahagia," Tiada Badai - Irvyn Wongso (ALPADH Cover). https://www.youtube.com/ watch? $\mathrm{v}=$ YGuE0da8JIE (accessed June 1, 2020).

True Direction. 2016. "Dhamma Is My Way - True Direction." https://www.youtube.com/ watch? $\mathrm{v}=7 \mathrm{kE} 1 \mathrm{ftXS} 85 \mathrm{~g}$ (accessed June 1, 2020).

True Direction. 2017a. "Mindful Eating during True Direction DMR (Dhamma \& Meditation Retreat)." https://www.facebook.com/truedirectionmusic/photos/a.674982635965709.1 073741828.674959772634662/1140115509452417/?type=3\&theater (accessed June 1, 2020).

True Direction. 2017b. “Sis @alingpang sedang berlatih dengan sangat tekun.” https://www. facebook.com/truedirectionmusic/photos/a.674982635965709.1073741828.6749597726

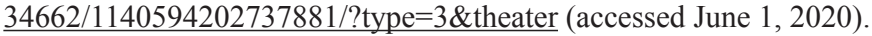

True Direction. 2017c. Odelia Sabrina Taslim @deasabrinat during Day 3 of True Direction DMR (Dhamma \& Meditation Retreat). https://www.facebook.com/truedirectionmusic/ photos/a.674982635965709.1073741828.674959772634662/1140696372727664/?type= 3\&theater (accessed June 1, 2020).

True Direction. 2017d. "Selamat Hari Natal kepada yang para sahabat merayakan dari para peserta True Direction DMR (Dhamma \& Meditation Retreat)." https://www.facebook. com/truedirectionmusic/photos/a.674982635965709.1073741828.674959772634662/114 $1269666003668 /$ ?type $=3 \&$ theater $($ accessed June 1, 2020).

True Direction. 2018. About. https://www.facebook.com/pg/truedirectionmusic/ about/?ref=page internal (accessed June 1, 2020).

Wales, H.G. Quaritch. 1951. The Making of Greater India: A Study in South-East Asian Culture Change. London: Bernard Quaritch.

Wolters, Oliver W. 1999. History, Culture, and Region in Southeast Asian Perspectives. Ithaca: SEAP Publications.

Wong, Ardy. 2017. Interview by Author. October 30.

Wongso, Irvyn. 2016a. "My First Ever Video Profile - Irvyn Wongso.” https://www.youtube. com/watch?v=iKDWP0fPly8 (accessed June 1, 2020).

Wongso, Irvyn. 2016b. "Music \& Buddhism. https://www.youtube.com/watch?v=qf2s03uv IM\&frags=wn (accessed June 1, 2020).

Wongso, Irvyn. 2016c. "Metta Moment Duet - Irvyn Wongso \& Imee Ooi." https://www. youtube.com/watch? $v=p 5 X K 5 R K O H t A$ (accessed June 1, 2020).

Wongso, Irvyn. 2016d. "Inspiring Moment with Bodhi KL." https://www.youtube.com/ watch?v=1TVpAn7LnPI (accessed June 1, 2020). 
Wongso, Irvyn. 2017a. Interview by Author. May 17.

Wongso, Irvyn. 2017b. "Rahasia Hati Odelia - True Direction Dhamma \& Meditation Retreat 2017." https://www.youtube.com/watch?v=6RhQp0WeIS4 (accessed June 1, 2020).

Wongso, Irvyn. 2017c. "Testimoni Bro Fian - True Direction Dhamma \& Meditation Retreat 2017." https://www.youtube.com/watch?v=jTMLtf6jU-U\&t=132s (accessed June 1, 2020).

Wongso, Irvyn. 2017d. "Meditasi Menumbuhkan Rasa Syukur (Nadia Mudita) - True Direction DMR 2017." https://www.youtube.com/watch?v=GY5KiZWGpQs (accessed June 1, 2020).

Zschech, Darlene. 2015. Change Your World. https://darlenezschech.com/home/product/ change-your-world/ (accessed June 1, 2020). 
